ROCZNIKI TEOLOGICZNE

Tom LXVI, zeszyt 1 - 2019

DOI:http://dx.doi.org/10.18290/rt.2019.66.1-2

REV. LEON SZOT

REV. MIROSŁAW KALINOWSKI

\title{
EXPEDITING HUMAN DIGNITY IN SOCIAL WORK PRACTICES
}

\begin{abstract}
A b s t r a c t. The authors explore the complexities of human dignity, analyze human dignity as a concept and its position within the framework of today's social work practices. In this regard, the authors ponder upon diverse understanding of human dignity, including human dignity as a socio-legal value and its importance to social work in general and to other principal values relevant for social work. They examine the evolution of social work approaches towards human dignity while focusing on social work related international organizations and their national members' and partners' work to promote and uphold human dignity in delivery processes of social services.
\end{abstract}

Key words: social work; human dignity; social work practice; social worker; social work code of ethics.

\section{INTRODUCTION - COMPLEXITIES OF HUMAN DIGNITY}

Human dignity's nature is widely uncontested and self-evident. Nevertheless, attempts to generate a common understanding for its meaning have displayed its convolution. ${ }^{1}$ Social work practices have so far proved that per-

Rev. Leon Szot - Dr hab., Prof. Member of Institute of Social Work at Pontifical University of John Paul II in Cracow, Poland; address: ul. Bernardyńska 3, 31-069 Kraków; e-mail: leon.szot@upjp2.edu.pl

Rev. Mirosław KALINOwSKI - Prof. Dr hab., Director of the Institute of Family Studies and Social Work, head of the Department of Social, Palliative and Hospice Care at the John Paul II Catholic University of Lublin, Poland; address: ul. Radziszewskiego 7, 20-039 Lublin; e-mail: kalinowskim@kul.pl

${ }^{1}$ A.B. MiszTAL, "The idea of Dignity; its Modern Significance," European Journal of Social Theory, 16(2013), 1: 363-371. 
ception of dignity correspondingly differs between persons just as perception of social justice. That said, connotation of dignity remains context-specific and varies from jurisdiction to jurisdiction and, in many instances, in the course of time within particular jurisdictions. ${ }^{2}$ Notwithstanding, the recent approach among social work practitioners, to import to a certain extent the understanding of human dignity as it is expressed by international legal instruments, paves the path for human dignity concept to further evolve within social work practices.

\section{HUMAN DIGNITY AS A SOCIO-LEGAL VALUE ${ }^{3}$}

At present, it is widely acknowledged that human dignity has three characteristics which have formed its modern meaning - it is a social value, it is a constitutional value as well as it has become a constitutional right. In its social meaning, human dignity has been a distinctive value in human societies of all times. The intellectual history of human dignity, as a social value, has been explored in philosophical and religious texts, literature and poetry of societies and their nations worldwide. Undoubtedly, Judaism and Christianity made a crucial contribution to develop a human dignity concept as it is known today. Certain ideas corresponding to the evolving western concept of human dignity are also widespread in major religions such as Buddhism, Confucianism, Hinduism and Islam, among the biggest tribal communities e.g. in the Maori Tribe ${ }^{4}$ as well as other human communities whether they hold monotheistic, secular or atheistic worldviews. ${ }^{5}$

Judaism uses the term "kavod" to define "dignity/honor" of God, in turn "kavod khaadam" relates to "human dignity" - God has dignity, thus as a man derives from God, he has his human dignity. In Christianity, imago dei taken form Judaism gave the basis for the revelation of Jesus and His attri-

\footnotetext{
${ }^{2}$ C. Mc CRUdDEn, "Human Dignity and Judicial Interpretation of Human Rights," European Journal of International Law, 19(2008), 4: 655-659.

${ }^{3}$ The author of this article analyzes these aspects of human dignity which he considers relevant for the social work perspective.

${ }^{4}$ A. BARAK, Human Dignity: The Constitutional Value and the Constitutional Right (Cambridge, 2015), 12-22.

${ }^{5}$ M. MAhLmanN, "Human Dignity and Autonomy in Modern Constitutional Orders," in: The Oxford Handbook of Comparative Constitutional Law, ed. M. Rosenfeld, A. Sajo (Oxford, 2012), 377-379.
} 
butes which he inherited as God's son, implicitly including dignity. Thomas Aquinas (1225-1274) affirmed that dignity "dignitas" was man's freedom to choose his goals, that man was goal himself and that when man sins, "he loses his human dignity". Other catholic theologians similarly acknowledged that man is a goal of himself, his ultimate goal is to know God while man's dignity encompassed his free will, eternal soul, rational actions and his ability to act morally ${ }^{6}$.

Two renowned philosophers extensively contributed to the built-up of human dignity concept. Pico della Mirandola (1463-1494) postulated that man's dignity came from his ability to choose what he wanted, while much later Locke (1632-1704) recognized that the rationality of man was his individuality. However, it was Kant (1724-1804), and his doctrines of ethics and morality, who had actually provided the well-founded basis of today's concept of human dignity both in social and legal terms. According to Kant, one acts ethically if she or he acts by force of his duty which a rational agent legislates itself upon his or her will. Duties to oneself - categorized as development of his/her talents as well as duties to others - called a contribution to one's happiness form the man's ability which is named "human dignity". This idea was part of Kant's ethics' doctrine. In turn, his doctrine of morality, which was elaborated upon the right of jurisprudence, included a principle of a person's universal right to choose her or his ends and realize them upon the condition that they comported with other people's identical freedom to choose their ends and ways of realization them. Most importantly, for Kant, humanity was itself a dignity. ${ }^{7}$

At present, Dworkin works have been considered to be returning the concept of human dignity. He postulates that two principles define the essence of human dignity: 1) every person has special objective value which is important not only to himself but to all of us; and 2) every person holds the responsibility for success in his own life. ${ }^{8}$ However, in order to provide a thorough examination of the contemporary social contexts regarding the human dignity debate, it is also necessary to touch upon everyday language and how the term "dignity" is there reflected and defined. The term "dignity", in all languages where it is used, it is connected to humans. Its ethical value is usually affirmed by its three meanings: 1) our dignity is respected by us if

\footnotetext{
${ }^{6}$ A. BARAK, Human Dignity, 15-22.

7 Id., 25-28.

${ }^{8}$ Id., 29.
} 
we act rightly, we lose dignity if we act wrongly; 2) we experience a feeling of indignity if we are treated not as we were supposed to be treated; and 3) dignity is our nature and it cannot be lost. ${ }^{9}$ The three meanings reflect religious and philosophical debates which have been carried for centuries until now. Whereas the first and the second meaning is more directly linked to religious contexts of the debate, the third one may be regarded as a result of both religious and philosophical debates, out of which the latter has predominantly mirrored doctrines of Kant.

Respect for dignity has been costly; it has required a human solidarity in deeds and words. ${ }^{10}$ That said, human dignity as a legal concept accomplishes diverse functions in constitutions, constitutional instruments and has become an important verification factor for international law instruments. Human dignity, in this context, serves as a normative for individual protection, is an objective law, one of the core principles of the law, a guideline which interpret other fundamental rights. Ultimately, it formulates principles responsible for the structure of the state and other legally and politically institutionalized transnational orders. Central components of human dignity as it has been perceived by its intellectual history - ungraspable essence of human beings, its uniqueness and self-determination and a need for protection against objectification of individuals - may be found in major legal interpretation, i.e. in international jurisprudence. Prominent contents indicating preservation of minimum standards of persons' treatment, protection of individual status and prohibition of objectification and instrumentalization of individuals are present in various jurisdictions worldwide. ${ }^{11}$

Human dignity as a constitutional value fulfills numerous functions in the domain of human rights as well as fundamental rights: it provides a theoretical framework for human rights' structure; it interprets human rights at subnational level; it is one of the values which every constitutional right is aimed to perform; it may be applied to limit constitutional rights; and it has a supreme interpretative roles in the cases where constitutions recognize rights to human dignity. Human dignity, in its constitutional aspect, is defined as "the humanity of each person as a human being", "...it is the freedom of choice of human beings and the autonomy of their will", "it is their human identity", it is the freedom from degradation and humiliation, “...pre-

\footnotetext{
${ }^{9}$ B. BAERTSCHI, "Human Dignity as a Component of a Long-Lasting and Widespread Conceptual Construct," Bioethical Inquiry, 11(2014), 201-211.

${ }^{10}$ M. Mahlmann, "Human Dignity," 379-380.

${ }^{11}$ Id., 395.
} 
venting anyone from turning into a means of satisfaction of another's will". In this context, human dignity functions within the bounds of society. Moreover, it constitutes a cornerstone of external and internal emotional realm of human beings, accounts for determination of human beings' social identity and structures relationship between them. ${ }^{12}$

Human dignity as a constitutional right is recognized in most modern constitutions, however usually this right is not absolute - as a relative right might be limited. In some constitutions, the right to human dignity is both positive and negative. Negatively - the state's obligations do not only refrain from imposing limitations on the right to human dignity, but positively take action to protect the right to human dignity. For instance, German constitutional law treats human dignity as not subject to any constitutional amendments ${ }^{13}$; the Constitution of India underlines securing fraternity which assures dignity of all individuals, particularly of children and women ${ }^{14}$ and derives the right to human dignity form the right to life; the Constitution of Spain postulates that human dignity is the inviolable and inherent right and "the foundation of political order and social peace"; whereas American Bill of Rights and the Canadian Charter of Human Rights were crafted in a manner to include an implied human dignity as fundamental value. ${ }^{15}$

\section{SOCIAL WORK VERSUS HUMAN DIGNITY - CODES OF ETHICS AND GENERAL PRINCIPLES}

The promotion of human dignity has been embedded in the ethics and values of all social workers associations; however its topical significance has particularly become evident since 2004. That year, in October, at the General Meetings of the International Federation of Social Workers ${ }^{16}$ and of the

\footnotetext{
12 A. BARAK, Human Dignity, 362-367.

${ }^{13}$ Ibid.

${ }^{14}$ The Constitution of India, available at: http://lawmin.nic.in/olwing/coi/coi-english/coi4March2016.pdf (23.05.2017).

15 A. BARAK, Human Dignity, 362.

16 The International Association of Social Workers (IFSW) is a global organization which supports its 126 member countries in the strife for social justice, human rights and social development through the promotion of social work. The IFSW has a Special Consultative Status at the United Nations Economic and Social Council (ECOSOC) and at the United Nations Children's Fund (UNICEF). The IFSW has cooperated on regular basis with the World Health Organization (WHO), the United Nations High Commissioner for Refugees (UNHCR)
} 
International Association of Schools of Social Work (IASSW) ${ }^{17}$ a document entitled "Ethics in Social Work, Statement of Principles" was approved in Adelaide, Australia. It is the first-ever statement of principles and ethics which should guide all social workers throughout the world notwithstanding political, constitutional and legal orders of the countries in which they perform their duties. According to the document, social workers' ability to act ethically and promote human rights and social justice is believed to be a standard quality which they should offer those in need of social work services. The document emphasizes that the purpose of the work of the IFSW and the IASSW is "to promote ethical debate and reflection in the member organizations, among the providers of social work in member countries as well as in the schools of social work and among social work students." It underlines diverse cultural and civilizational contexts through an emphasis on some difficult ethical challenges with which social workers are confronted in particular countries. $^{18}$

The statement of ethics identifies the following, most common ethical dilemmas of social workers worldwide which could have some detrimental effect on social workers' efforts to promote human dignity and social justice: 1) social workers' loyalty is in many cases in the midst of conflicting interests; 2) a must to operate as both controllers and helpers; 3) a growing conflict between the need to protect their clients and societal requirements for their utility and efficiency; and 4) limited resources within societies which would upgrade social work effects. The document refers to the following declarations and conventions pertaining to social work practices and human dignity: the Universal Declaration of Human Rights, the International Covenant on Civil and Political Rights, the International Covenant on Economic

and the United Nations High Commissioner for Human Rights. The organization also cooperates with national associations of social workers of their member countries. The IFSW was established in Munich in 1950. Its predecessor - the International Association of Social Workers - was formed in Paris at the Conference of Social Work in Paris in 1928. Available at: http://ifsw.org/what-we-do/, 12.04.2017.

17 The International Association of Schools of Social Work (IASSW) is a worldwide association of social work schools, social work educators and tertiary level social work education programs. The Association promotes the development of social work and develops standards for social work education and awareness. It was funded in 1928 in Paris. The Association initially comprised 51 schools. Revitalized after the II World war, it has gradually expanded its membership. At present, it has 459 member schools and 250 individual members. Available at: https://www.iassw-aiets.org/our-members/ (12.05.2017).

18 InTERnAtional Federation of SOCIAL Workers, Ethics in Social Work, Statement of Ethical Principles, available at: http://ifsw.org/policies/statement-of-ethical-principles/ (4.07.2017). 
Social and Cultural Rights, the Convention on the Elimination of all Forms of Racial Discrimination, the Convention on the Elimination of All Forms of Discrimination against Women, the Convention on the Rights of the Child and the Indigenous and Tribal Peoples Convention (ILO convention 169). ${ }^{19}$ This affirmation of international legal instruments points out noticeably at the need, often expressed by social work leaders and educators - that social work practices should rely to a greater extent on these instruments as a source to practice their ethics and should be used to compromise their ethical dilemmas.

The document emphasizes that social work "is based on respect for the inherent worth and dignity of all people and the rights that follow from this. Social workers should uphold and defend each person's physical, psychological, emotional and spiritual integrity and well-being." The document further explains that this avowal means: 1) respecting the right to self-determination - social workers should promote their client's rights to make choices irrespectively of their own life values and choices, however under no condition rights of others cannot be threaten by clients' choices; 2) promoting the right to participation - social workers should favour the full involvement and participation of their clients in the society through enabling them empowerment of their decisions and choices; 3) treating clients individually but each person as whole - social workers should interact not only with the client but also with his family, community, societal and natural environments and should recognize the client's life; 4) identifying and developing strengths social workers should concentrate on client's, groups' and communities' strengths to promote their empowerment within society. ${ }^{20}$ This approach clearly outlines how respect for human dignity should encompass a wide range of daily social work practices, including framing a social worker client relationship. While the text regarding human dignity enumerates main components and characteristics of social workers' duties, it eventually stresses the importance of human dignity promotion, which actually was not a per se so much recognized value in the past decades of social work movements. ${ }^{21}$

Another theme which is closely linked with the human dignity promotion in the document is social justice. In accordance with the text, social workers are responsible for promotion of social justice in society in general and

\footnotetext{
${ }^{19}$ Ibid.

${ }^{20}$ Ibid.

${ }^{21}$ IASSW, ICSW, IFSW, Global Agenda for Social Work and Social Development Commitment to Action (Berne, 2012), 1.
} 
among their clients. The text further clarifies that social workers should challenge negative discrimination based on ability, age, gender or sex, marital status, culture, political opinions, socio-economic status, race, skin color, other physical characteristics, sexual orientation or spiritual beliefs. Social workers in some countries, which cultural contexts require such action, should promote positive discrimination to redress the effects of so-called "historical discrimination" against groups which have been affected by its consequences. In addition, social workers should recognize diversity and respect ethnic and cultural differences, distribute resources equitably within which they perform societies their duties and make attempts to challenge unjust practices and policies while work in solidarity towards an inclusive society. ${ }^{22}$

In addition, a distinct attachment to human dignity is evident in the part of the document regarding the professional conduct of social workers. Thereby it is stated that national organizations' responsibility in membership of both the IFSW and the IASSW is to develop and regularly update their own ethical guidelines or codes of ethics so that they are consistent with the IFSW/ IASSW statement. The document underscored that it is the responsibility of national organizations to inform their social workers and schools of social work about the codes of ethics or ethical guidelines. That said social workers are expected to act according to up-to-date ethical codes of their countries, i.e. among others they should act with integrity, trust, compassion, care and empathy without using their skills for inhumane purposes such as terrorism, torture or without abusing their position for personal gains. They also should keep confidentiality of their clients' information unless disclosing them might be justifiable in the event of a "greater ethical requirement" such as the preservation of life. Social workers should be obliged to develop their skills through appropriate training curtailed to societal conditions of their countries as well as they should create conditions in their workplace to debate and evaluate national ethical codes. ${ }^{23}$

Although the document states that its authors are aware of "some" ISFW/IASSW member countries' ethical nuances stemming from various socio-cultural contexts, the purpose of having it agreed and launched was to attempt and unify ethical codes of the ISFW members as well as to influence

\footnotetext{
${ }^{22}$ International Federation of SOCIAL WORKERS, Ethics in Social Work... available at: http://ifsw.org/policies/statement-of-ethical-principles/ (10.07.2017).

${ }^{23}$ Ibid.
} 
these members whose ethical codes had vaguely reminded European or North American codes. Diverse approaches to human dignity in ethical codes affirm cultural, political and legal orders' differences among IFSW member countries. For instance, the British Association of Social Workers accentuates that social work grew out of humanitarian ideals and that it values are based on dignity, equality and worth and that dignity should be approached as it is expressed in the United Nations Universal Declaration of Human Rights. The promotion and upholding of human dignity as well as supporting people's dignity are key principles of the British ethical code. ${ }^{24}$ The Russian Social Educators and Social Workers' Union's ethical guidelines refer to human dignity in the context of tolerance stressing the need to support, protect and promote it as an important human value. ${ }^{25}$ The South Korea Association of Social Workers' code of ethics articulates human dignity in the context of respecting it in the relationship "social worker-client," it treats social work profession as dignity itself and stresses that social workers' actions "should not hurt" dignity of other professions. ${ }^{26}$ The French code of ethics emphasizes its attachment to principles of the Universal Declaration of Human Rights, among others to the principle of human dignity which is to play a crucial role in the social work profession and it underlines the importance of protecting dignity of the client. ${ }^{27}$ The American National Association of Social Workers' code of ethics, which is considered as very detailed and most elaborated among national codes, places the value of human dignity next to worth of the person and the importance of human relationships. It highlights the necessity to protect dignity of the client next to his privacy and well-being. ${ }^{28}$

Per comparison, the Israeli Association for Advancement of Social Work's code of ethics does not mention dignity, ${ }^{29}$ whereas for example the Nigerian

\footnotetext{
${ }^{24}$ The British Association of Social Workers, "The Code of Ethics for Social Work, Statement of Principles," Birmingham January (2012), 5-8.

25 The Russian Public Organization, The Union of Social Educators and Social WORKERS, The Ethical Guideline of Social Educator and Social Worker (Moscow, 2003), 6-18.

${ }^{26}$ KOREA AsSOCIATION OF SOCIAL WORKERS, Korea Association of Social Workers Ethics Code, available at: http://cdn.ifsw.org/assets/ifsw_12405-10.pdf (13.07.2017).

${ }^{27}$ L'Association Nationale des Assistants Sociaux, Code de l'ANAS, Code de Déontologie, available at: http://ifsw.org/publications/national-codes-of-ethics/france/ (2.06.2017).

${ }^{28}$ National Association of Social Workers, Code of Ethics of the National Association of Social Workers, available at: http://www.socialworkers.org/pubs/code/code.asp (14. 05.2017).

29 The Association for the Advancement of Social Work, Code of Professional
} 
Association of Social Workers' code of ethics barely mentions that human dignity should be respected as much as the worth of a person. ${ }^{30}$ In turn, the China Association of Social Workers' code of conduct has minor differences in some constructs as well as in the ranking order of value dimensions from Western models ${ }^{31}$; however its reference to human dignity is unnoticeable and focused on the needs-based approach rather than rights-based approach. ${ }^{32}$ The Code of Practice for Registered Social Workers in Hong Kong does not mention human dignity, however it focuses on respecting cultural differences based on ethnic origin, religion and custom. ${ }^{33}$

\section{SOCIAL WORK VERSUS HUMAN DIGNITY AND HUMAN RIGHTS}

The importance of human dignity has further grown in relevance over recent years - respect for the "dignity and worth of peoples" became the second pillar of the Global Agenda for Social Work and Social Development which was established in 2010 jointly by the IFSW, the IASSW and the International Council on Social Welfare (ICSW). ${ }^{34}$ The pillar's goals have been outlined in three groups: 1) the role of IFSW, IASSW and ICSW in supporting the United Nations and other international agencies; 2) the role of IFSW, IASSW and ICSW in providing services to communities and other partners; and 3) the role of IFSW, IASSW and ICSW in improving work quality within their own organizations. The IFSW, IASSW and ICSW identified the following goals to support the United Nations: 1) seeking universal implementation of the international conventions and other instruments which relate to political, civil, socio-economic

Ethics of the Social Workers in Israel, available at: http://ifsw.org/publications/national-codesof-ethics/israel/ (13.05.2017).

${ }^{30}$ NASOW, Code of Ethics, available at: http://nasowabuja.org.ng/code-of-ethics/ (13.05. 2017).

${ }^{31}$ F. ZHAO, F. FU, B. YANG, "Social Work Value System in mainland China: Construction of a Scale and Value Commitment Assessment," in: International Social Work, 12(2017) January, available at: http://journals.sagepub.com/doi/10.1177/0020872816682582 (23.05.2017).

32 X. Guan, The Development of Professional Social Work in China (Paris, 2017), 1-24.

33 Social Workers Registration Board Hong Kong, Code of Practice for Registered Social Workers, available at: https://www.swrb.org.hk/en/Content.asp?Uid=15 (12.04.2017).

${ }^{34}$ IASSW, ICSW, IFSW, Global Agenda for Social Work and Social Development Commitment to Action, 1. Other pillars of the Global Agenda for Social Work and Social Development are: promoting of social and economic inequalities, working toward environmental sustainability, strengthening recognition of importance of human relationships. 
and cultural rights; 2) promoting social strategies which would build inclusive and cohesive societies; 3 ) seeking renewed commitment to peaceful resolutions of conflicts; 4) working with partners to challenge violent state responses; 5) advocating for the peoples' rights which would enable them moving from one country to another and providing undocumented migrants access to social services; and 6) working towards reducing human trafficking. The IFSW, IASSW and ICSW committed themselves to work with communities and other partners to support communities in prevention of violent conflicts, to support actions taken by partner organizations to enhance rights of transnational migrants, to combat human trafficking and promote cultural identity. Lastly, The IFSW, IASSW and ICSW obliged to ask their members: 1) to closely cooperate and ensure that legislation and social work practices would not hamper the right to undertake legitimate and democratic activities related to social work; 2) to promote respect for diversity and enhance training and education programs for social work particularly in the field of ethical and informed interventions; and 3) to promote practice and education standards which would be effective in conflict resolution practices, human trafficking and consequences of migration. ${ }^{35}$

In the course of last seven years, two reports were issued which provided an in-depth analysis of the realization of the pillar and its goals in five regions/regional observatories: Europe, Asia Pacific, Africa, Latin America and the Caribbean, North America and the Caribbean. ${ }^{36}$ The first progress report provided a sort of stock-taking information about initiatives being undertaken by the IFSW, IASSW and ICSW. The second progress report of the Global Agenda presented its findings in $2016 .{ }^{37}$ Both reports together are of particular value due to several important reasons. They could be evaluated as in fact harbingers of change and improvement concerning approaches towards human dignity in social work practices and social development. They provided both global and regional reviews of social work development; outlined characteristics of social work challenges for each examined region; and offered recommendations for social work development. Moreover, the report's authors resorted to support the reviews and recommendations which they presented through the use of scientific research methods, including detailed surveys, and field interviews. All these reasons make this report valuable for social work researchers and practitioners

\footnotetext{
35 Id., 3.

${ }^{36}$ IASSW, ICSW, IFSW, Global Agenda for Social Work and Social Development Commitment to Action: Second Report (Berne, 2016), 5-25.

${ }^{37}$ Ibid.
} 
to follow up on concrete proposals and possibilities to include them in social work research and education programs.

The observatories of the second report examined the social work situation in the context of social, political and economic realities in 2014-2016. The observatories regardless the region, concluded that sustainable social development might be best achieved only if social work professionals and people their clients work together with mutual respect co-constructing solutions to difficult social problems which affected community, family or individuals by personal trauma, mistreatment or calamities. The report stated that lack of respect for human dignity and worth of people was evident throughout all examined regions and was caused by discrimination and mistreatment based on age, race, gender, being a member of minority groups, being disabled or affected by particular health conditions. Those who did not have access to safe environment, drinking water and had no stable prospects for the future suffered most from the lack of dignity. The report underlined that living conditions were heavily influenced by socio-economic divides and inequalities and that these economic and social realities made the lack of human dignity a practical challenge for social work professionals. The report stressed that social protection systems should be universal and designed in a manner to promote the dignity; they should be tools for social transformation; energize solidarity of communities, self-determination and democratic participation; and be constructed upon a strong foundation of international human rights law. It articulated that a lack of social protection floor in some countries with austerity policies was observed. The report strongly signaled that the imposition of neo-liberal economic policies had increased socio-economic inequalities among countries so that the poorer became poorer and the rich - richer. It emphasized that social workers based in austerity countries had not received salaries for months, were at times forced into becoming homeless. It was recognized that in the light of the refugee crisis which had affected Europe and the Middle East, social workers played a leading role in "humanizing the face of refugees to concerned host communities," in assisting them in integration with their new communities. ${ }^{38}$

With regard to the Africa region, the report's authors used a qualitative survey with open-ended questions which was downloaded on the Qualtrics platform. In addition, they invited its respondents to submit case studies on social work development in the region. Eleven countries participated in the

\footnotetext{
38 Ibid.
} 
study and the survey: Burundi, Ethiopia, Lesotho, Liberia, Kenya, Nigeria, Rwanda, South Africa, Uganda, Tanzania and Zimbabwe. The findings were grouped in several categories which reflect the region's situation vis-à-vis human dignity: 1) areas of vulnerability impinging human dignity - which were identified in the forms of poverty, inequality, unemployment, conflict and post-conflict traumas, domestic violence, internal and external displacements, homelessness, heavily polluted environment, poor access to drinking water and sanitation, serious child neglect and abuse, socio-economic deprivation, prostitution, promiscuous behavior and mental health illnesses; 2) promoting the dignity of social service users; 3 ) interventions in communities which promote human dignity; 4) social work, human dignity and human rights' education; 5) challenges in promoting human dignity; 6) comparative studies in promoting human dignity in affected areas. The findings of the Africa region included among others the following observations: 1) best practices sharing continues to be the most effective tool for social work practitioners; 2) the dignity learning should be a lived experience that should challenge ones' prejudices, oppressions, worldviews and privileges; 3) dignity must be role-modelled in practical life contexts; 4) lack of human rights' protective systems, inadequate resources and poor infrastructure limit social workers' activity in rural areas; 5) the social work profession needs its role to be recognized by both societies and affected communities if social change is to take place at all; 6) interdependency of challenges to promote human dignity should be jointly addressed by social work educators, policy makers and researchers; and 7) human dignity should be adopted as the core commitment for practice, policy and teaching. ${ }^{39}$

The Asia Pacific region was presented through a different lens approach due to its more diverse socio-economic and political realities as well as disparate roles played by social work in the region. Other tools were used to support social work reviews, recommendations and challenges. The report's authors compiled records of social work related workshops, conferences and interviews from the following countries: Australia, Bangladesh, Hong Kong, Indonesia, India, Japan, New Zealand, Nepal and the Philippines. Although this part of the report is far less specific than other parts concerning other regions, it still offers an interesting insight into major problems with which this region's social workers have to deal with in their daily routine work. An

${ }^{39}$ A. LOMBARD, J. TwIKIRIZE, “Africa Region,” in: IASSW, ICSW, IFSW, Global Agenda for Social Work and Social Development Commitment to Action: Second Report, 35-60. 
absence of traditions associated with respect for human rights, the exploitation of child labor; including migrant child labor, human trafficking and poverty are considered to be serious problems to social development in $\mathrm{Ne}$ pal, India, Bangladesh, Philippines and Thailand while mental health related issues, including social isolation brought about by dementia and other elderly peoples' diseases continues to pose threats to social development across the region, particularly in Indonesia, Japan and Malaysia. A key initiative to address vulnerabilities of indigenous people in the region, in the event of natural disasters' consequences, was presented by Australian social workers as a potential role-model to be used in other parts of the word affected by recurrent natural disaster. ${ }^{40}$

The part of the report on the European region presented a different approach to social work practice and focused on human dignity promotion from a perspective of the projects-based approach, which reflects highly evolving nature of today's European social work. The analysis was prepared by joint efforts of the European Network of Social Action (ENSACT) partners. ${ }^{41}$ The text recalled Lorenz's statement that "modern forms of societies require new forms of social contracts which social workers can pioneer in their daily encounters with those individuals and groups most threatened with total bond disruption, abandonment and exclusion." The report is grouped in three categories: practice, education and policy. Inputs were received from 15 countries: Belgium, Belarus, Bulgaria, Denmark, Finland, Germany, Iceland, France, Lithuania, the Netherlands, Portugal, Slovakia, Spain, Sweden and the United Kingdom. The European social work practitioners addressed the following issues in the presented projects: 1) methods to further develop social work practice; 2) gap-mending in social work education; 3) working with students to structure future generations of social workers; 4) mobilization of social service users in practice development; 5) working closely with clients to fight against the loss of social ties in society and supporting clients' independency. The human dignity promotion projects were at times organized in an unordinary manner, in a form of campaigns in parks or media to attract the attention and engage as much as possible social services' recipients, their

${ }^{40}$ B. RAJU NiKKU, R. HENDERSON (ed.), "Asia Pacific Region,” in: IASSW, ICSW, IFSW, Global Agenda for Social Work and Social Development Commitment to Action: Second Report, 61-70.

${ }^{41}$ The ENSACT, the largest European platform for social work practitioners' cooperation, was established in 2007 in response to promote human rights-based approach in social work practice and social work education. Available at: http://www.ensact.com/ (15.03.2017). 
direct communities and surrounding environments. The presented projects were summarized in the words: "respect, awareness, perspectives, facilitation and partnership" and recognized human dignity as a core value of social work and social work education. ${ }^{42}$

The Latin America and Caribbean region resorted to the use of qualitative methodology and development of a guide of questions with open answers which were responded in a digital format. The responses were received from seventeen countries: Argentina, Bolivia, Brazil, Chile, Colombia, Costa Rica, the Dominican Republic, Ecuador, Guatemala, Honduras, Mexico, Nicaragua, Peru, Puerto Rico, El Salvador, Uruguay and Venezuela. The following issues connected to the promotion of human dignity and worth were addressed by the region's social workers, social work educators and social work academia: 1) identification of social work problems; 2) methods of linking social work practices with the promotion of human dignity; 3) the role of human dignity promotion in intervention practices; 4) methods, procedures and techniques used in social work; 5) theoretical frameworks for social work profession; and 6) description of results achieved by social work practice. In total 162 case studies were submitted, while 28 were analyzed to support the findings of the report. The report's authors pointed at poverty, inequalities in income distribution, lack of educational background, poor access to health systems, unemployment, unresolved political conflicts and precarious conditions of labor as major challenges to social development in the region. They underlined a wide and unusual diversity of social work profession in the region, which for instance included assistance of individuals and communities at obtaining university scholarships, protecting consumer rights, accessing public infrastructure, struggling against of armed conflicts, university teaching, preventing from bulling, supporting transgender communities and promoting itercultural relationships. The central finding of the report was in fact a question, which should be answered in consultation by all social work practitioners, concerning methods of pinpointing rights-based approaches for social work development in the region; particularly in locations where the clients lived below the subsistence level. ${ }^{43}$

\footnotetext{
${ }^{42}$ K. SVENSSON, "European Region," in: IASSW, ICSW, IFSW, Global Agenda for Social Work and Social Development Commitment to Action: Second Report, 71-100.

${ }^{43}$ M.L. Actis, J. Oyaneder, L. Marangunic, L.M. Aguilar Perez, M.I.B. Benjamin Rivera, C.P. Reales VÁsquez, M.A. Robles Barja, D.P. Claudio, S. Martinez, "Latin America and Caribbean Region," in: IASSW, ICSW, IFSW, Global Agenda for Social Work and Social Development Commitment to Action: Second Report, 101-124.
} 
Last of all, the North America and Caribbean region's report was presented in the light of positive socio-political changes which predominantly resulted from the elections of the new president - Justin Trudeau in Canada and Barack Obama in the United States, which both promoted the rights of women and minority groups, social services rights and criticized such social problems as police brutality. The Council of Social Work Education (CSWE) members authored the report. The CSWE collected inputs for the report from social work practitioners via e-mail. The Canadian social work community shared media alerts, dissertations, reports, websites and published articles regarding the promotion of human dignity in combating violence against women; supporting the rights of gender diverse youth to choose their identities; protecting rights of Aboriginal children and their families; developing disaster mitigation strategies; and assisting in rebuilding of lives of incoming refugees. This community also presented a policy draft - Social Care Act for Canada of their authorship, in which they laid great stress on ensuring human and social rights of their clients, transparency and fairness of social workers' actions as well as they issued a proposal for a guaranteed annual income for every Canadian citizen, which could be financed by the federal government. In this part of the report, social workers professionals from the Caribbean's Barbados, Guyana, Trinidad and Tobago enumerated disaster management in case of tropical storms and hurricanes; youth and child neglect, discrimination - particularly of transgender persons and sex workers; protection of elderly people against social exclusion; and supporting migrant communities as main issues with which they deal with on daily basis. In turn, the United States social work community emphasized twelve major goals which they attempted to accomplish in their daily routine: 1) ensuring healthy youth development; 2) closing and addressing the health gap; 3) advancing productive and long lives; 5) eradicating social isolation; 6) ending homelessness; 7) creating social responses to changing environments; 8) harnessing technologies for social good; 9) forming financial capability of all clients; 10) reducing "extreme economic inequalities"; 11) promoting "smart decarceration"; and 12) providing social justice and equal opportunities for all clients. The United States social work professionals stressed the need to reinvigorate the social work through the Social Work Reinvestment Act designed to address such challenges as: fair market compensation, high social work educational debt, lack of diversity of the social work practice, poor safety of social workers and a lack of a state level social work licensure. The professionals underlined the importance of the NASW code of ethics as a core document for their practice, the importance of human rights-based approach in social work prac- 
tices and their growing engagement in addressing social issues such as criminal justice, HIV-Aids, violence against women, mental health problems, ageing, themes related to migration and refugees as well as a necessity to increase support to the military and veterans. ${ }^{44}$

Concluding, human dignity has become a crosscutting theme which commences to underpin raison d' tre of the social work profession. Moreover, its robust connection to human rights-based approach as well as projects-based approach to social work practices is noticeable in Europe, North America, while its starts to influence the social work profession in Africa and Latin America. A question remains to be posed how the issue of human dignity influences social work in the Middle East. In addition, a thorough examination of human dignity concepts is required to be conducted in the Asia Pacific region. Subsequently, human dignity as the crosscutting theme for the social work profession might be further evaluated and measured through the use of statistical sociological tools and identification of variables - themes relevant to human dignity concepts.

\section{BIBLIOGRAPHY}

Actis, M.L., Oyaneder, J., Marangunic L., Aguilar Perez, L.M., Benjamin Rivera, M.I.B., Reales Vásquez, C.P., Robles Barja, M.A., Claudio, D.P., Martinez, S. "Latin America and Caribbean Region." In: IASSW, ICSW, IFSW. Global Agenda for Social Work and Social Development Commitment to Action: Second Report, 101-124. Berne, 2016.

BAERTSCHI B. "Human Dignity as a Component of a Long-Lasting and Widespread Conceptual Construct." Bioethical Inquiry 11(2014), 201-211.

The British Association of Social Workers. "The Code of Ethics for Social Work, Statement of Principles." Birmingham January 2012.

CSWE (ed.). "North America and Caribbean." In: IASSW, ICSW, IFSW. Global Agenda for Social Work and Social Development Commitment to Action: Second Report, 137-156. Berne, 2016.

Guan, X. The Development of Professional Social Work in China. Paris, 2017.

IASSW, ICSW, IFSW. Global Agenda for Social Work and Social Development Commitment to Action. Berne, 2012.

IASSW, ICSW, IFSW, Global Agenda for Social Work and Social Development Commitment to Action: Second Report. Berne, 2016.

${ }^{44}$ CSWE (ed.), "North America and Caribbean," in: IASSW, ICSW, IFSW, Global Agenda for Social Work and Social Development Commitment to Action: Second Report, 137-156. 
LOMBARD, A., TwikirIZE, J., “Africa Region.” In: IASSW, ICSW, IFSW. Global Agenda for Social Work and Social Development Commitment to Action: Second Report, 35-60. Berne, 2016.

Mahlmann, M., "Human Dignity and Autonomy in Modern Constitutional Orders." In: The Oxford Handbook of Comparative Constitutional Law. Ed. M. Rosenfeld, A. Sajo, 377-379. Oxford, 2012.

Mc C., CRUdDEN. "Human Dignity and Judicial Interpretation of Human Rights." European Journal of International Law 19(2008), 4: 655-724.

MiszTAL, A.B. "The idea of Dignit: its Modern Significance." European Journal of Social Theory 19(2013), 4: 363-371.

Raju NikKu, B., Henderson, R. (ed.). "Asia Pacific Region.” In: IASSW, ICSW, IFSW. Global Agenda for Social Work and Social Development Commitment to Action: Second Report, 61-70. Berne, 2016.

The Russian Public Organization, The Union of Social Educators and Social WorKERS. The Ethical Guideline of Social Educator and Social Worker. Moscow, 2003.

SVENSSON, K. "European Region.” In: IASSW, ICSW, IFSW. Global Agenda for Social Work and Social Development Commitment to Action: Second Report, 71-100. Berne, 2016.

http://cdn.ifsw.org/assets/ifsw_12405-10.pdf

http://www.ensact.com/

https://www.iassw-aiets.org/our-members/

http://ifsw.org/policies/statement-of-ethical-principles/

http://ifsw.org/publications/national-codes-of-ethics/france/

http://ifsw.org/publications/national-codes-of-ethics/israel/

http://ifsw.org/what-we-do/

http://journals.sagepub.com/doi/10.1177/0020872816682582

http://lawmin.nic.in/olwing/coi/coi-english/coi-4March2016.pdf

http://nasowabuja.org.ng/code-of-ethics/

http://www.socialworkers.org/pubs/code/code.asp

https://www.swrb.org.hk/en/Content.asp?Uid=15

\section{LUDZKA GODNOŚĆ \\ W PRAKTYCE PRACY SPOŁECZNEJ}

\section{S t r e s z c z e n i e}

Autorzy dokonują analizy złożoności zagadnienia godności ludzkiej oraz godności ludzkiej jako koncepcji oraz jej umiejscowienia w ramach dzisiejszych form i praktyk pracy społecznej. W związku z tym autorzy rozważają tematykę pojmowania godności ludzkiej, w tym godności ludzkiej jako wartości społeczno-prawnej, jej istotności dla pracy społecznej w ogóle oraz z racji podstawowych wartości relewantnych dla pracy społecznej. Autorzy egzaminują ewolucję podejść pracy społecznej wobec godności ludzkiej koncentrując się na działalności organizacji międzynarodowych, ich członków stowarzyszonych i partnerów związanych z pracą społeczną, których zadaniem jest m.in. promować oraz dbać o przestrzeganie wartości godności ludzkiej w dostarczaniu codziennych praktyk i usług pracy społecznej.

Słowa kluczowe: praca społeczna; godność człowieka; praktyka pracy socjalnej; pracownik socjalny; kodeks etyki pracy socjalnej. 